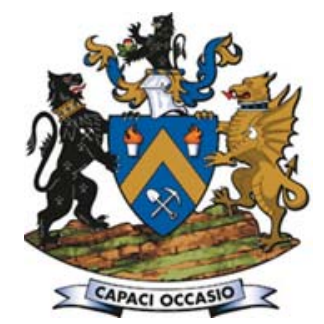

\title{
A model to calculate blasting costs using hole diameter, uniaxial compressive strength, and joint set orientation
}

\author{
by A. Ghanizadeh Zarghami*, K. Shahriar ${ }^{\dagger}$, K. Goshtasbi ${ }^{\ddagger}$, \\ and A. Akbaris
}

\section{Synopsis}

Calculation of the blasting costs plays a significant role in blast pattern design and reduction of the final extraction cost of minerals. Blasting costs include drilling costs, blasting materials costs, and additional costs of blasting operations. We assessed information from three copper mines in Iran, and found that there is a significant relationship between blasting costs and hole diameter. A relationship was derived to calculate blasting costs per cubic metre as a function of hole diameter, bench height, uniaxial compressive strength, joint set orientation, the cost of drilling, and the unit cost of explosives. This model will enable engineers to estimate blasting costs prior to designing the blast pattern. Based on the model, an increase in the rock strength and the angle between the bench face and the main joint set will increase the blasting cost. On the other hand, the costs will decrease when the hole diameter increases for every range of uniaxial compressive strength.

Keywords

Blasting cost, hole diameter, uniaxial compressive strength, joint set, Iran copper mines.

\section{Introduction}

Reduction of the operating costs is of great importance with respect to the final costs of the product. The ability to estimate blasting costs before designing blast patterns enables design engineers to choose suitable blast-hole diameters and other crucial parameters of the blast design (Ghanizadeh Zarghami, 2005). Specific charge and specific drilling are two substantial factors concerning blast pattern design that influence blasting costs

(Ghanizadeh Zarghami et al., 2017). The hole diameter is generally regarded as a crucial parameter in designing blast patterns (Ostovar, 2013). In the same vein, this study, proposes several models to estimate blasting costs as a function of hole diameter and other parameters, including uniaxial compressive strength (UCS).

\section{Research objective}

Blasting models have been formulated by applying technical and economic information on blasting operations at three large copper mines in Iran, namely Sungun, Miduk, and Chah-Firouzeh (Figure 1), After determining the hole diameter and rock uniaxial compressive strength, it will be possible to calculate blasting costs for these three mines and similar operations.
Various investigations have been conducted with the aim of reducing blast operation costs. Afum and Temeng (2014) explored various parameters affecting drilling cost and blast optimization in a gold mine in Ghana. At this mine, blasting was done in three different blocks. The blasting and crushing costs were affected by parameters such as the ground conditions and blast pattern. The model was employed in order to regulate the costs by testing suggested patterns. The results indicated a decrease of between 5.3 and $12.2 \%$ in ore costs and between 2.9 and $14.8 \%$ for waste costs.

Adebayo and Akande (2015) investigated the effects of drilling in terms of blast-hole deviation and muck-pile loading costs for six scenarios at Hwange Colliery, Zimbabwe. The study showed that the drilling and operational costs were in the range of US\$0.13-7.53 per $\mathrm{m}^{3}$. Ancillary costs of drilling increased from US $\$ 1.7$ to US $\$ 4.2$ per $\mathrm{m}^{3}$ with an increase in blast-hole deviation from $7 \%$ gradient to $21 \%$.

Adebayo and Mutandwa (2015) evaluated the relationship between blast-hole deviation, fragment size, and fragmentation cost. The use of ANFO, heavy ANFO, and emulsion explosives in holes $191 \mathrm{~mm}$ and $311 \mathrm{~mm}$ in diameter was compared using six scenarios. The results showed that as blast-hole deviation increases the mean fragment size decreases and the cost of drilling and blasting increases. Increasing the hole diameter from $191 \mathrm{~mm}$ to $311 \mathrm{~mm}$ increased the blast fragmentation.
* Department of Mining Engineering, Science and Research Branch, Islamic Azad University, Tehran, Iran.

+ Department of Mining and Metallurgy Engineering, Amir Kabir University, Iran.

\# Department of Mining Engineering, Faculty of Engineering, Tarbiat Modares University, Iran.

$\S$ Department of Mining Engineering, Islamic Azad University of Tehran Central, Iran.

(c) The Southern African Institute of Mining and Metallurgy, 2018. ISSN 2225-6253. Paper received Mar. 2018; revised paper received Apr. 2018. 


\section{A model to calculate blasting costs using hole diameter, uniaxial compressive strength}

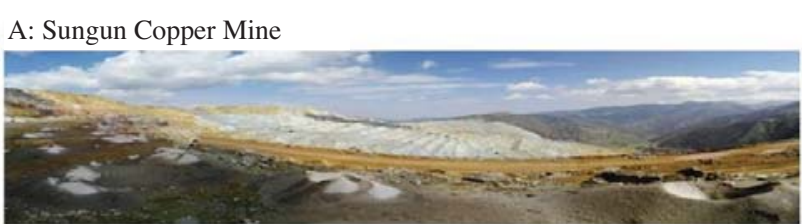

B: Miduk Copper Mine

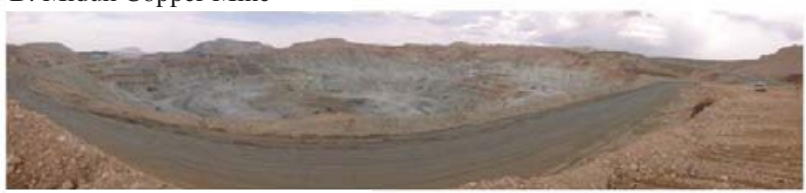

C: Chah-Firouzeh Copper Mine

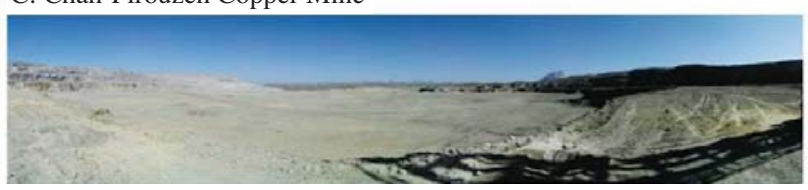

Figure 1-Perspective views of Sungun, Miduk, and Chah-Firouzeh copper mines

Nenuw and Jimoh (2014) designed and optimized the blasting parameters to reduce the damaging effects and blasting costs by using Langfors and other common blast formulae. In this study, which was conducted at four mines, parameters such as burden, spacing, bench height, hole diameter, the number of holes, bottom charge, and total charge per hole were examined and the planned and actual costs calculated. The actual costs of blasting material were higher than the calculated cost, which required modification and revision.

Cunningham (2013) investigated four key parameters that determine the ability to design an effective blast in terms of delay timing and cost. These parameters included heave control and monitoring, hole diameter, and explosive type.

Strelec, Gazdek, and Mesec (2011) designed an optimized blast pattern to reduce drilling costs. The blast fragmentation was optimized by applying the calibration factors in the KuzRam model.

Eloranta (1995) showed, by comparing the loading costs of materials to the blasting costs, that due to the increase in specific explosive charge in large-diameter holes, the blasting costs have a strong inverse correlation with the specific explosives charge. Increasing the specific explosives charge by $15 \%$ increased the shovel and crusher efficiencies by $5 \%$, resulting in an overall reduction in operating costs.

\section{Blasting blocks information}

More than 4600 records of blasting operations at Sungun, Miduk, and Chah-Firouzeh from 2012 to 2014 were collected. Incorrect and unreliable records were deleted and finally, 2414 blasts with limited back break, air blast, ground vibration, oversize, and destructive effects were selected. Basic information on the blasting operations, including drilling costs, blasting material, and blast block geometry for the three mines is shown in Table I (Ghanizadeh Zarghami, 2017).

In Table I, the mines are categorized according to rock strength. The drilling cost per metre is considered according to the contractor price, and the cost for ANFO is based on the purchase price, transport, and delivery to the mine. The types of rocks blasted are shown in Table II.

\section{The choice of effective parameters}

The large number of factors and the complicated iterations make it impossible to determine the theoretical consumption of explosives at the present level of development in blasting theory. Thus, recourse is made either to practical data or to empirical formulae that generalize blasting practice in application to drifting (Pokrovsky, 1980). In the present research, four important parameters: hole diameter, UCS, joint set orientation, and bench height were selected for calculating blasting cost. These parameters could be easily calculated by the engineers and ultimately aid in estimating the blasting costs.

\section{Blasting pattern and cost calculations}

The correct ratios between the geometric parameters of blasting patterns and hole diameter in the UCS range between 10 and $250 \mathrm{MPa}$ and for the angle between the bench face and main joint set $(\gamma)<90^{\circ}$ and $>90^{\circ}$ were extracted from the blasting databases at the respective mines. These ratios are presented in Tables III and IV. In the same UCS range, more energy is required when $\gamma$ is greater than $90^{\circ}$ because the joint set dips in the opposite direction to the free face direction. Therefore, the specific charge and specific drilling, and blasting costs are higher for $\gamma>90^{\circ}$ than for $\gamma<90^{\circ}$ (Ghanizadeh Zarghami, 2017).

According to the rules of block theory, the angle between the bench face and the main joint set is important. This angle is located between the two normal vectors of the planes. In other words, $\gamma$ is the same angle between the two planes and

$$
\text { Table I }
$$

Data of drilling costs, explosives, and bench geometry considering compressive strength

\begin{tabular}{|l|c|c|c|c|}
\hline Mine & $\begin{array}{c}\text { Chah- } \\
\text { Firouzeh }\end{array}$ & Miduk & $\begin{array}{c}\text { Miduk and } \\
\text { Sungun }\end{array}$ & Sungun \\
\hline UCS $(\mathrm{MPa})$ & $10-70$ & $70-120$ & $120-180$ & $180-250$ \\
\hline Length of block $(\mathrm{m})$ & 70 & 70 & 70 & 70 \\
\hline Width of block $(\mathrm{m})$ & 150 & 150 & 150 & 150 \\
\hline Bench height $(\mathrm{m})$ & 15 & 15 & 15 & 15 \\
\hline ANFO density $\left(\mathrm{t} / \mathrm{m}^{3}\right)$ & 0.88 & 0.88 & 0.88 & 0.88 \\
\hline Volume of block $\left(\mathrm{m}^{3}\right)$ & 157500 & 157500 & 157500 & 157500 \\
\hline $\begin{array}{l}\text { Drilling cost }\left(\mathrm{US} \$ / \mathrm{m}^{3}\right) \\
(6 \text { inches diameter in 2017) }\end{array}$ & 4.5 & 5.4 & 6.48 & 7.77 \\
\hline $\begin{array}{l}\text { Price of ANFO }(2017) \\
(U S \$ \text { /kg) }\end{array}$ & 0.73 & 0.73 & 0.73 & 0.73 \\
\hline
\end{tabular}

\section{Table II}

Rock types at the three case study copper mine

\begin{tabular}{|l|c|c|c|c|}
\hline No. & Mine & Rock type & Description & UCS (MPa) \\
\hline 1 & Miduk & Waste & Andesite & $70-120$ \\
\hline 2 & Miduk & Mixed & $\begin{array}{c}\text { Andesite and } \\
\text { granodiorite }\end{array}$ & $120-180$ \\
\hline 3 & Miduk & Ore & Granodiorite & $120-180$ \\
\hline 4 & Sungun & Waste & Trachyte & $180-250$ \\
\hline 5 & Sungun & Ore & Monzonite & $120-180$ \\
\hline 6 & Chah-Firouzeh & Waste & Alluvium & $10-70$ \\
\hline
\end{tabular}




\section{A model to calculate blasting costs using hole diameter, uniaxial compressive strength}

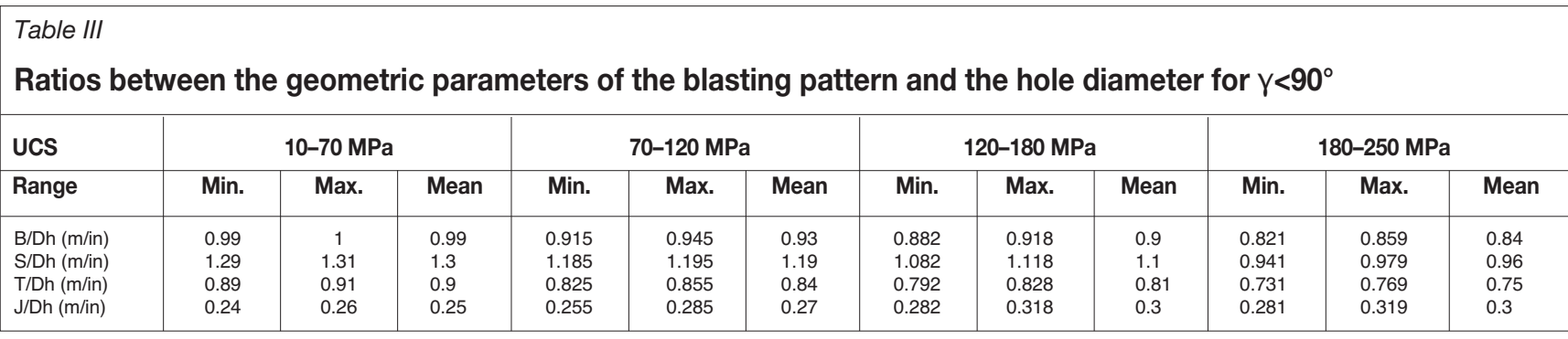

Table IV

Ratios between the geometric parameters of the blasting pattern and the hole diameter for $\gamma>90^{\circ}$

\begin{tabular}{|c|c|c|c|c|c|c|c|c|c|c|c|c|}
\hline \multirow{2}{*}{$\begin{array}{l}\text { UCS(MPa) } \\
\text { Range }\end{array}$} & \multicolumn{3}{|c|}{$10-70 \mathrm{MPa}$} & \multicolumn{3}{|c|}{$70-120 \mathrm{MPa}$} & \multicolumn{3}{|c|}{$120-180 \mathrm{MPa}$} & \multicolumn{3}{|c|}{$180-250 \mathrm{MPa}$} \\
\hline & Min. & Max. & Mean & Min. & Max. & Mean & Min. & Max. & Mean & Min. & Max. & Mean \\
\hline $\mathrm{B} / \mathrm{Dh}$ (m/in) & 0.699 & 1.161 & 0.93 & 0.599 & 1.201 & 0.9 & 0.81 & 0.87 & 0.84 & 0.76 & 0.8 & 0.78 \\
\hline $\mathrm{S} / \mathrm{Dh}(\mathrm{m} / \mathrm{in})$ & 1.18 & 1.2 & 1.19 & 0.899 & 1.301 & 1.1 & 0.94 & 0.98 & 0.96 & 0.794 & 0.866 & 0.83 \\
\hline T/Dh (m/in) & 0.828 & 0.852 & 0.84 & 0.78 & 0.84 & 0.81 & 0.725 & 0.775 & 0.75 & 0.47 & 0.93 & 0.7 \\
\hline $\mathrm{J} / \mathrm{Dh}(\mathrm{m} / \mathrm{in})$ & 0.24 & 0.3 & 0.27 & 0.299 & 0.301 & 0.3 & 0.28 & 0.32 & 0.3 & 0.27 & 0.33 & 0.3 \\
\hline
\end{tabular}

it is a necessary factor for writing the equation of plane, dip, and dip direction of the plane. The dip and dip direction of the main joint set and bench face are of importance to present the equation of their plane. Equation [1] demonstrates the plane equation and Equation [2] represents the coordinates of normal vector through dip and dip direction (Dehghan, 2001). Figure 2 shows the layout of the angles and plane.

$$
\begin{aligned}
& A X+B Y+C Z=D \\
& A=\sin \alpha \sin \beta \\
& B=\sin \alpha \cos \beta \\
& C=\cos \alpha
\end{aligned}
$$

In Equation [2], $\alpha$ indicates the dip and $\beta$ represents dip direction relative to north. Equation [3] is used to measure the angle between the two planes $(\mathrm{Y})$.

$$
\begin{gathered}
P_{1}\left(\alpha_{1}, \beta_{1}\right) \rightarrow \hat{n}_{1}=\left(A_{1}, B_{1}, C_{1}\right) \\
P_{2}\left(\alpha_{2}, \beta_{2}\right) \rightarrow \hat{n}_{2}=\left(A_{2}, B_{2}, C_{2}\right) \\
y=\cos ^{-1}\left(\frac{A_{1}, A_{2}, B_{1}, B_{2},+C_{1}, C_{2},}{\sqrt{\left(A_{1}^{2}+B_{1}^{2}+C_{1}^{2}\right)\left(A_{2}^{2}+B_{2}^{2}+C_{2}^{2}\right)}}\right.
\end{gathered}
$$

All blasting costs were modelled in the Comfar technical and economic analysis software and the cost per cubic metre broken was calculated. As presented in Table V, $87 \%$ of the blasting operation costs depends on the cost of ANFO and drilling costs. Equation [4] shows the cost of blasting operations according to specific drilling, specific charge, the price per kilogram of ANFO, and drilling cost per metre (Ghanizadeh Zarghami, 2017).

$$
\begin{aligned}
& C_{1}+C_{2}=87 \% B C, B C=(1 / 0.87)\left(C_{1}+C_{2}\right), \\
& B C=1.15\left(P_{A} \times S C+P_{D} \times S D\right)
\end{aligned}
$$

In Equation [4], parameter $C_{1}$ represents ANFO cost, $C_{2}$ represents drilling cost, $B C$ represents blasting cost per cubic metre, $P_{A}$ the price of ANFO per kilogram, $P_{D}$ the price of drilling per metre, $S C$ the specific charge $\left(\mathrm{kg} / \mathrm{m}^{3}\right)$, and $S D$ the specific drilling $\left(\mathrm{m} / \mathrm{m}^{3}\right)$.
Tables VI to IX show the burden, spacing, stemming, and sub-drilling considering the rock strength with $\gamma<90^{\circ}$ and $\gamma>90^{\circ}$. At the studied mines, hole diameters of 6 to 6.5 inches are used. The burden parameter, spacing, stemming, and sub-drilling in zone classification of UCS were calculated according to joint set orientation with a hole diameter of 6 inches $(152.4 \mathrm{~mm})$.

\section{Discussion and review}

Factors in the blasting operation costs include blasting material costs and auxiliary costs such as staff wages, transportation, storage, and overhead costs. The bulk of the costs includes the blasting costs and consists of the drilling costs and the cost of ANFO. Finally, considering the contractor costs, the blast side cost was equal to $15 \%$ of the total cost.

The cost of drilling operations and consumed specific costs were calculated through burden, spacing, stemming, and sub-drilling. Parameter calculations and the operational costs in rocks with UCS of 10 to $70 \mathrm{MPa}$ and hole diameters of 2 to 16 inches are presented in Table $X$, for $\gamma<90^{\circ}$.

According to Table VI, for $\gamma>90^{\circ}$, the same calculations were carried out based on Table X, the results of which, along with the results of calculations for $\gamma<90^{\circ}$, are shown in Figure 3.

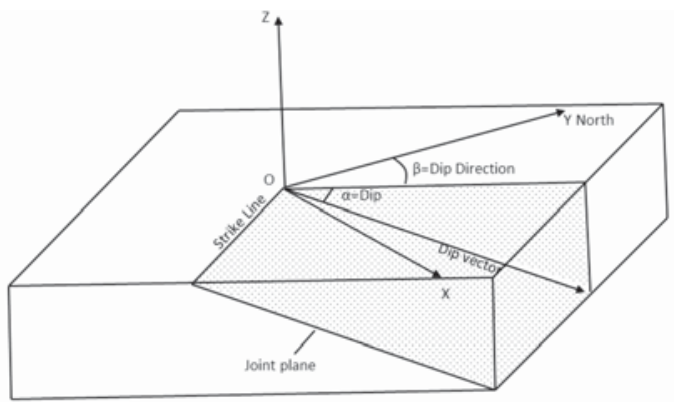

Figure 2-Layout of the angles and plane (Dehghan, 2001) 


\section{A model to calculate blasting costs using hole diameter, uniaxial compressive strength}

\section{Table $V$}

The ratio of ANFO costs and drilling costs to the total blasting costs

\begin{tabular}{|c|c|c|c|c|c|c|c|c|c|c|}
\hline No. & Mine & Type & Year & $\begin{array}{l}\text { Blasting cost } \\
\left(1000 \text { Rials } / m^{3}\right)\end{array}$ & $\begin{array}{c}\text { Production } \\
\text { volumes }\left(m^{3}\right)\end{array}$ & $\begin{array}{l}\text { ANFO cost }+ \text { drilling } \\
\text { cost }(1000 \text { Rials) (A) }\end{array}$ & $\begin{array}{l}\text { Drilling cost } \\
\text { (1000 Rials) }\end{array}$ & $\begin{array}{l}\text { ANFO cost } \\
\text { (1000 Rials) }\end{array}$ & $\begin{array}{l}\text { Total blasting cost } \\
\text { (1000 Rials) (B) }\end{array}$ & $\begin{array}{c}\text { Ratio } \\
\text { A/B }\end{array}$ \\
\hline 1 & Miduk & Waste & 2012 & 13.67 & 3931645 & 48863950 & 16528950 & 32335000 & 53739619 & $91 \%$ \\
\hline 2 & Miduk & Waste & 2013 & 14.83 & 2460168 & 33736800 & 10861800 & 22875000 & 36487558 & $92 \%$ \\
\hline 3 & Miduk & Waste & 2014 & 14.07 & 1021837 & 12349950 & 3627450 & 8722500 & 14377475 & $86 \%$ \\
\hline 4 & Miduk & Mixed & 2012 & 14.32 & 1952261 & 23644850 & 8024850 & 15620000 & 27959571 & $85 \%$ \\
\hline 5 & Miduk & Mixed & 2013 & 15.42 & 2802693 & 38499100 & 11924100 & 26575000 & 43215594 & $89 \%$ \\
\hline 6 & Miduk & Mixed & 2014 & 13.27 & 5981862 & 72757900 & 22107900 & 50650000 & 79380906 & $92 \%$ \\
\hline 7 & Miduk & Ore & 2012 & 15.05 & 1430466 & 15393550 & 5176050 & 10217500 & 21529271 & $72 \%$ \\
\hline 8 & Miduk & Ore & 2013 & 21.81 & 1010146 & 13553350 & 4679100 & 8874250 & 22027611 & $62 \%$ \\
\hline 9 & Miduk & Ore & 2014 & 18.79 & 1002165 & 11914000 & 3939000 & 7975000 & 18831301 & $63 \%$ \\
\hline 10 & Sungun & Waste & 2012 & 32.18 & 624178 & 18668700 & 6610950 & 12057750 & 20085600 & $93 \%$ \\
\hline 11 & Sungun & Waste & 2013 & 34.62 & 147914 & 3914 725 & 1410450 & 2504275 & 5120925 & $76 \%$ \\
\hline 12 & Sungun & Waste & 2014 & 40.21 & 315153 & 11390050 & 4014000 & 7376050 & 12672690 & $90 \%$ \\
\hline 13 & Sungun & Ore & 2012 & 13.52 & 7698287 & 101487100 & 35356350 & 66130750 & 104078530 & $98 \%$ \\
\hline 14 & Sungun & Ore & 2013 & 14.19 & 6777431 & 93713950 & 32721450 & 60992500 & 96188900 & $97 \%$ \\
\hline 15 & Sungun & Ore & 2014 & 14.37 & 6562884 & 91971600 & 31918800 & 60052800 & 94300530 & $98 \%$ \\
\hline 16 & Chah-Firouzeh & Waste & 2012 & 18.12 & 2702430 & 45956250 & 15142500 & 30813750 & 48973369 & $94 \%$ \\
\hline 17 & Chah-Firouzeh & Waste & 2013 & 15.32 & 3742393 & 54760000 & 21303750 & 33456250 & 57345636 & $95 \%$ \\
\hline 18 & Chah-Firouzeh & Waste & 2014 & 13.39 & 3098502 & 39060050 & 13063800 & 25996250 & 41480320 & $94 \%$ \\
\hline \multicolumn{7}{|c|}{$\begin{array}{l}\text { *In 2017: } \$ 1=37000 \text { Rials } \\
\text { Iran's currency is the Rial }\end{array}$} & & & Mean: & $87.01 \%$ \\
\hline
\end{tabular}

Table VI

Blast pattern parameters at Chah-Firouzeh copper mine, UCS 10-70 MPa and hole diameter 6 inches

\begin{tabular}{|c|c|c|c|c|c|c|}
\hline $\begin{array}{l}\text { Variable parameters } \\
\text { of blast pattern }\end{array}$ & \multicolumn{2}{|c|}{$\begin{array}{l}\text { Ratios UCS }=10-70 \\
\operatorname{Mpa~}\left(\gamma<90^{\circ}\right)\end{array}$} & $\begin{array}{c}\text { Computational v alues } \\
\text { Dh }=6 \text { in }\end{array}$ & \multicolumn{2}{|c|}{$\begin{array}{c}\text { Ratios UCS }=10-70 \\
\mathrm{Mpa}\left(\gamma>90^{\circ}\right)\end{array}$} & $\begin{array}{c}\begin{array}{c}\text { Computational values } \\
\text { Dh=6 in }\end{array} \\
5580\end{array}$ \\
\hline $\begin{array}{l}\text { Burden } \\
\text { Spacing } \\
\text { Stemming length } \\
\text { Sub drilling length }\end{array}$ & $\begin{array}{l}\text { B/Dh } \\
\text { S/Dh } \\
\text { T/Dh } \\
\text { J/Dh }\end{array}$ & $\begin{array}{l}0.99 \\
1.3 \\
0.9 \\
0.25\end{array}$ & $\begin{array}{l}5940 \\
7722 \\
5346 \\
1485\end{array}$ & $\begin{array}{l}\text { B/Dh } \\
\text { S/Dh } \\
\text { T/Dh } \\
\text { J/Dh }\end{array}$ & $\begin{array}{l}0.93 \\
1.19 \\
0.84 \\
0.27\end{array}$ & $\begin{array}{l}5580 \\
7142 \\
5022 \\
1618\end{array}$ \\
\hline
\end{tabular}

Table VII

Blast pattern parameters at Miduk copper mine, UCS 70-120 MPa and hole diameter 6 inches

\begin{tabular}{|c|c|c|c|c|c|c|}
\hline $\begin{array}{l}\text { Variable parameters } \\
\text { of blast pattern }\end{array}$ & \multicolumn{2}{|c|}{$\begin{array}{c}\text { Ratios UCS }=70-120 \\
\mathrm{Mpa}\left(\gamma<90^{\circ}\right)\end{array}$} & $\begin{array}{l}\text { Computational values } \\
\text { Dh }=6 \text { in }\end{array}$ & \multicolumn{2}{|c|}{$\begin{array}{c}\text { Ratios UCS }=70-120 \\
M p a\left(\gamma>90^{\circ}\right)\end{array}$} & $\begin{array}{c}\text { Computational values } \\
\text { Dh=6 in }\end{array}$ \\
\hline $\begin{array}{l}\text { Burden } \\
\text { Spacing } \\
\text { Stemming length } \\
\text { Sub drilling length }\end{array}$ & $\begin{array}{l}\text { B/Dh } \\
\text { S/Dh } \\
\text { T/Dh } \\
\text { J/Dh }\end{array}$ & $\begin{array}{l}0.93 \\
1.19 \\
0.84 \\
0.27\end{array}$ & $\begin{array}{l}5580 \\
7142 \\
5022 \\
1618\end{array}$ & $\begin{array}{l}\text { B/Dh } \\
\text { S/Dh } \\
\text { T/Dh } \\
\text { J/Dh }\end{array}$ & $\begin{array}{l}0.9 \\
1.1 \\
0.81 \\
0.3\end{array}$ & $\begin{array}{l}5400 \\
6588 \\
4860 \\
1782\end{array}$ \\
\hline
\end{tabular}

Table VIII

Blast pattern parameters at Miduk and Sungun copper mine, UCS 120-180 MPa and hole diameter 6 inches

\begin{tabular}{|c|c|c|c|c|c|c|}
\hline $\begin{array}{l}\text { Variable parameters } \\
\text { of blast pattern }\end{array}$ & \multicolumn{2}{|c|}{$\begin{array}{c}\text { Ratios UCS }=120-180 \\
\mathrm{Mpa}\left(\gamma<90^{\circ}\right)\end{array}$} & $\begin{array}{l}\text { Computational values } \\
\text { Dh }=6 \text { in } \\
5400\end{array}$ & \multicolumn{2}{|c|}{$\begin{array}{c}\text { Ratios UCS }=120-180 \\
\text { Mpa }\left(\gamma>90^{\circ}\right)\end{array}$} & $\begin{array}{c}\text { Computational values } \\
\text { Dh=6 in }\end{array}$ \\
\hline $\begin{array}{l}\text { Burden } \\
\text { Spacing } \\
\text { Stemming length } \\
\text { Sub drilling length }\end{array}$ & $\begin{array}{l}\text { B/Dh } \\
\text { S/Dh } \\
\text { T/Dh } \\
\text { J/Dh }\end{array}$ & $\begin{array}{l}0.9 \\
1.1 \\
0.81 \\
0.3\end{array}$ & $\begin{array}{l}5400 \\
6588 \\
4860 \\
1782\end{array}$ & $\begin{array}{l}\text { B/Dh } \\
\text { S/Dh } \\
\text { T/Dh } \\
\text { J/Dh }\end{array}$ & $\begin{array}{l}0.84 \\
0.96 \\
0.75 \\
0.3\end{array}$ & $\begin{array}{l}5040 \\
5746 \\
4486 \\
1799\end{array}$ \\
\hline
\end{tabular}




\section{A model to calculate blasting costs using hole diameter, uniaxial compressive strength}

Table IX

Blast pattern parameters at Sungun copper mine, UCS 180-250 MPa and hole diameter 6 inches

\begin{tabular}{|c|c|c|c|c|c|c|}
\hline $\begin{array}{l}\text { Variable parameters } \\
\text { of blast pattern }\end{array}$ & \multicolumn{2}{|c|}{$\begin{array}{c}\text { Ratios UCS }=180-250 \\
\mathrm{Mpa}\left(\gamma<90^{\circ}\right)\end{array}$} & $\begin{array}{c}\text { Computational values } \\
\qquad \begin{array}{c}\text { Dh }=6 \text { in } \\
5040 \\
57468\end{array}\end{array}$ & \multicolumn{2}{|c|}{$\begin{array}{c}\text { Ratios UCS }=180-250 \\
\mathrm{Mpa}\left(\gamma>90^{\circ}\right)\end{array}$} & $\begin{array}{c}\begin{array}{c}\text { Computational values } \\
\text { Dh }=6 \text { in }\end{array} \\
4680\end{array}$ \\
\hline $\begin{array}{l}\text { Burden } \\
\text { Spacing } \\
\text { Stemming length } \\
\text { Sub drilling length }\end{array}$ & $\begin{array}{l}\text { B/Dh } \\
\text { S/Dh } \\
\text { T/Dh } \\
\text { J/Dh }\end{array}$ & $\begin{array}{l}0.84 \\
0.96 \\
0.75 \\
0.3\end{array}$ & $\begin{array}{c}5040 \\
57468 \\
4486 \\
1799\end{array}$ & $\begin{array}{l}\mathrm{B} / \mathrm{Dh} \\
\mathrm{S} / \mathrm{Dh} \\
\mathrm{T} / \mathrm{Dh} \\
\mathrm{J} / \mathrm{Dh}\end{array}$ & $\begin{array}{l}0.78 \\
0.83 \\
0.7 \\
0.3\end{array}$ & $\begin{array}{l}4680 \\
4961 \\
4165 \\
1778\end{array}$ \\
\hline
\end{tabular}

Table $X$

Calculations of blasting parameters and costs with UCS 10-70 MPa and hole diameter of 2 to 16 inches

\begin{tabular}{|c|c|c|c|c|c|c|c|c|c|c|c|c|c|c|c|c|c|}
\hline \multicolumn{2}{|c|}{$10-70 \mathrm{MPa}$} & Dh (in) & 2 & 3 & 4 & 5 & 6 & 7 & 8 & 9 & 10 & 11 & 12 & 13 & 14 & 15 & 16 \\
\hline \multicolumn{2}{|c|}{ Ratio is rounded (m/in) } & $\mathrm{Dh}(\mathrm{mm})$ & 50.8 & 76.2 & 102 & 127 & 152 & 178 & 203.2 & 228.6 & 254 & 279.4 & 304.8 & 330.2 & 355.6 & 381 & 406.4 \\
\hline $\mathrm{B} / \mathrm{Dh}$ & 0.99 & $B(\mathrm{~mm})$ & 1980 & 2970 & 3960 & 4950 & 5940 & 6930 & 7920 & 8910 & 9900 & 10890 & 11880 & 12870 & 13860 & 14850 & 15840 \\
\hline $\mathrm{S} / \mathrm{Dh}$ & 1.3 & $\mathrm{~S}(\mathrm{~mm})$ & 2574 & 3861 & 5148 & 6435 & 7722 & 9009 & 10296 & 11583 & 12870 & 14157 & 15444 & 16731 & 18018 & 19305 & 20592 \\
\hline T/Dh & 0.9 & $\mathrm{~T}(\mathrm{~mm})$ & 1782 & 2673 & 3564 & 4455 & 5346 & 6237 & 7128 & 8019 & 8910 & 9801 & 10692 & 11583 & 12474 & 13365 & 14256 \\
\hline$\overline{J / D h}$ & 0.25 & $\mathrm{~J}(\mathrm{~mm})$ & 495 & 742.5 & 990 & 1237.5 & 1485 & 1732.5 & 1980 & 2227.5 & 2475 & 2722.5 & 2970 & 3217.5 & 3465 & 3712.5 & 3960 \\
\hline \multicolumn{3}{|c|}{$\mathrm{SC}\left(\mathrm{kg} / \mathrm{m}^{3}\right)$} & 0.32 & 0.3 & 0.29 & 0.27 & 0.26 & 0.24 & 0.229 & 0.214 & 0.199 & 0.184 & 0.1694 & 0.154 & 0.139 & 0.124 & 0.109 \\
\hline \multicolumn{3}{|c|}{$\mathrm{SD}\left(\mathrm{m} / \mathrm{m}^{3}\right)$} & 0.2 & 0.09 & 0.05 & 0.03 & 0.02 & 0.02 & 0.014 & 0.011 & 0.009 & 0.008 & 0.0065 & 0.006 & 0.005 & 0.004 & 0.004 \\
\hline \multicolumn{3}{|c|}{ Drilling cost $(1000 \$)$} & 141 & 63.5 & 36.3 & 23.6 & 16.6 & 12.4 & 9.635 & 7.724 & 6.346 & 5.319 & 4.532 & 3.915 & 3.421 & 3.02 & 2.69 \\
\hline \multicolumn{3}{|c|}{ ANFO cost $(1000 \$)$} & 37 & 35.2 & 33.5 & 31.8 & 30 & 28.3 & 26.57 & 24.83 & 23.09 & 21.36 & 19.618 & 17.88 & 16.14 & 14.41 & 12.67 \\
\hline \multicolumn{3}{|c|}{$\begin{array}{l}\text { The lateral blast costs the } \\
\text { equivalent of } 13 \% \text { of the } \\
\text { total }(1000 \$)\end{array}$} & 26.6 & 14.8 & 10.5 & 8.3 & 7 & 6.11 & 5.43 & 4.883 & 4.416 & 4.001 & 3.6226 & 3.269 & 2.935 & 2.614 & 2.304 \\
\hline \multicolumn{3}{|c|}{$\begin{array}{l}\text { Blasting operation total } \\
\text { cost }(1000 \$)\end{array}$} & 204 & 114 & 80.3 & 63.7 & 53.7 & 46.8 & 41.63 & 37.44 & 33.85 & 30.68 & 27.773 & 25.07 & 22.5 & 20.04 & 17.67 \\
\hline \multicolumn{3}{|c|}{$\begin{array}{l}\text { Blasting operation total } \\
\operatorname{cost}\left(\$ / \mathrm{m}^{3}\right)\end{array}$} & 1.3 & 0.72 & 0.51 & 0.4 & 0.34 & 0.3 & 0.264 & 0.238 & 0.215 & 0.195 & 0.1763 & 0.159 & 0.143 & 0.127 & 0.112 \\
\hline
\end{tabular}

a: $\mathrm{SC}\left(\mathrm{Kg} / \mathrm{m}^{3}\right)$ and $\mathrm{SD}\left(\mathrm{m} / \mathrm{m}^{3}\right)$ and $\mathrm{BC}\left(\mathrm{S} / \mathrm{m}^{3}\right)$, if $\left(\mathrm{Y}<90^{\circ}\right)$
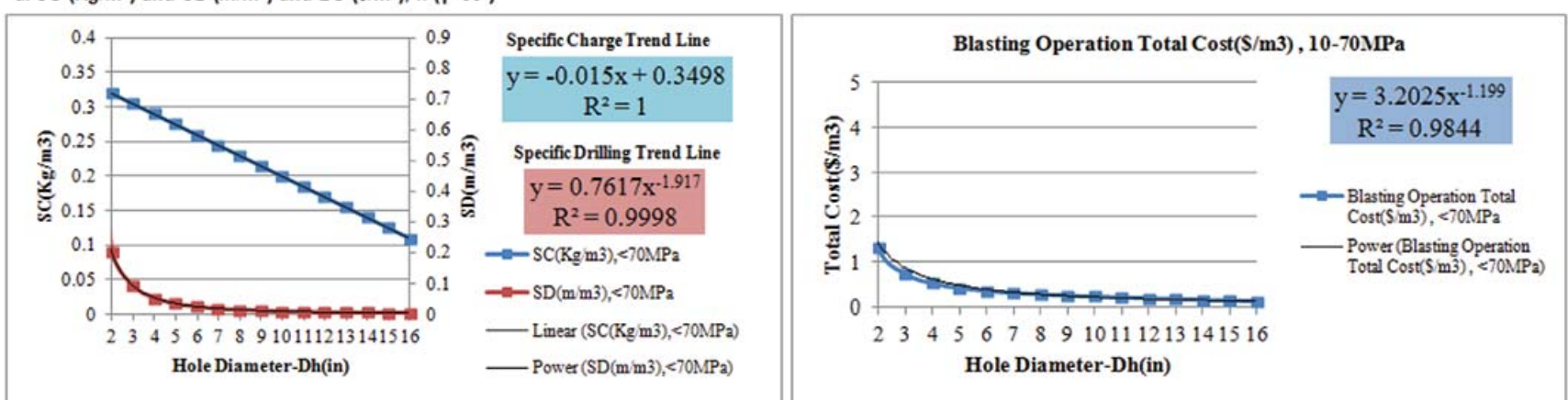

b: $\mathrm{SC}\left(\mathrm{Kg} / \mathrm{m}^{3}\right)$ and $\mathrm{SD}\left(\mathrm{m} / \mathrm{m}^{3}\right)$ and $\mathrm{BC}\left(\mathrm{S} / \mathrm{m}^{3}\right)$, if $\left(\mathrm{p}>90^{\circ}\right)$
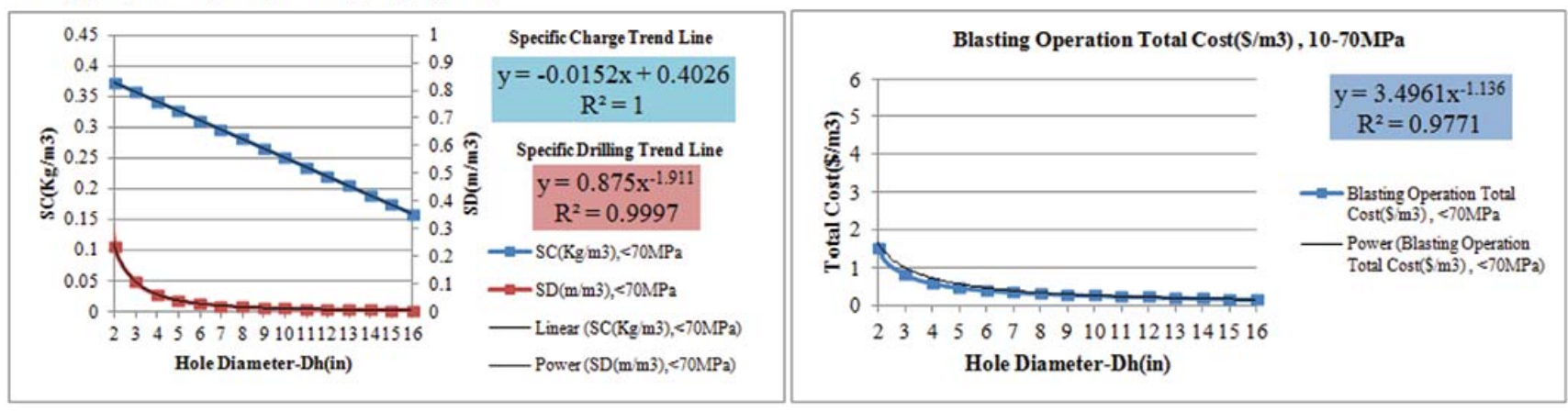

Figure 3-Relationship between of specific charge (SC), specific drilling (SD), and blasting costs considering hole diameter in the UCS range of $10-70$ MPa for $\gamma<90^{\circ}$ and $\gamma>90^{\circ}$ 


\section{A model to calculate blasting costs using hole diameter, uniaxial compressive strength}

For other rock strengths in the three mines, the tables of calculated blast parameters and diagrams are presented together. Table XI lists the parameters and blasting costs in rock with a strength of 70-120 MPa and with hole diameters of 2 to 16 inches.

According to Table VII, for $\gamma>90^{\circ}$, the same calculations were carried out based on Table XI, the results of which, along with the results of calculations for $\gamma<90^{\circ}$, are shown in Figure 4.

Table XII shows the parameters and blasting costs in rock with the strength of 120 to $180 \mathrm{MPa}$ and hole diameters of 2 to 16 inches.
According to Table VIII, for $\gamma>90^{\circ}$, the same calculations were carried out based on Table XII, the results of which, along with the results of calculations for $\gamma<90^{\circ}$, are shown in Figure 5.

Table XIII shows calculations of parameters and blasting costs in rock with strength between 180 to $250 \mathrm{MPa}$ and hole diameters of 2 to 16 inches.

According to Table IX, for $\gamma>90^{\circ}$, the same calculations were carried out based on Table XIII, the results of which, along with the results of calculations for $\gamma<90^{\circ}$, are shown in Figure 6.

\begin{tabular}{|c|c|c|c|c|c|c|c|c|c|c|c|c|c|c|c|c|c|}
\hline \multicolumn{18}{|c|}{$\begin{array}{l}\text { Table XI } \\
\text { Calculations of blasting parameters and costs with UCS 70-120 MPa and hole diameter of } 2 \text { to } 16 \text { inches }\end{array}$} \\
\hline \multicolumn{2}{|c|}{$70-120 \mathrm{MPa}$} & Dh (in) & 2 & 3 & 4 & 5 & 6 & 7 & 8 & 9 & 10 & 11 & 12 & 13 & 14 & 15 & 16 \\
\hline \multicolumn{2}{|c|}{ Ratio is rounded (m/in) } & Dh (mm) & 50.8 & 76.2 & 102 & 127 & 152 & 178 & 203.2 & 228.6 & 254 & 279.4 & 304.8 & 330.2 & 355.6 & 381 & 406.4 \\
\hline $\mathrm{B} / \mathrm{Dh}$ & 0.93 & $B(\mathrm{~mm})$ & 1860 & 2790 & 3720 & 4650 & 5580 & 6510 & 7440 & 8370 & 9300 & 10230 & 11160 & 12090 & 13020 & 13950 & 14880 \\
\hline S/Dh & 1.19 & $\mathrm{~S}(\mathrm{~mm})$ & 2380.8 & 3571.2 & 4761.6 & 5952 & 7142.4 & 8332.8 & 9523.2 & 10713.6 & 11904 & 13094.4 & 14284.8 & 5475.2 & 6665.6 & 17856 & 9046.4 \\
\hline T/Dh & 0.84 & $\mathrm{~T}(\mathrm{~mm})$ & 1674 & 2511 & 3348 & 4185 & 5022 & 5859 & 6696 & 7533 & 8370 & 9207 & 10044 & 10881 & 11718 & 12555 & 13392 \\
\hline J/Dh & 0.27 & $\mathrm{~J}(\mathrm{~mm})$ & 539.4 & 809.1 & 1078.8 & 1348.5 & \begin{tabular}{|l|}
1618.2 \\
\end{tabular} & 1887.9 & 2157.6 & 2427.3 & 2697 & 2966.7 & 3236.4 & 3506.1 & 3775.8 & 4045.5 & 4315.2 \\
\hline $\mathrm{SC}\left(\mathrm{kg} / \mathrm{m}^{3}\right)$ & & & 0.372 & 0.357 & 0.342 & 0.326 & 0.311 & 0.296 & 0.281 & 0.266 & 0.250 & 0.235 & 0.220 & 0.205 & 0.189 & 0.174 & 0.159 \\
\hline \multicolumn{2}{|l|}{$\mathrm{SD}\left(\mathrm{m} / \mathrm{m}^{3}\right)$} & & 0.234 & 0.106 & 0.061 & 0.039 & 0.028 & 0.021 & 0.016 & 0.013 & 0.011 & 0.009 & 0.008 & 0.007 & 0.006 & 0.005 & 0.005 \\
\hline \multicolumn{3}{|c|}{ Drilling cost $(1000 \$)$} & 195.07 & 88.20 & 50.46 & 32.84 & 23.18 & 17.31 & 13.46 & 10.80 & 8.89 & 7.46 & 6.36 & 5.50 & 4.81 & 4.25 & 3.79 \\
\hline \multicolumn{3}{|c|}{ ANFO cost (1000 \$) } & 43.09 & 41.33 & 39.57 & 37.81 & 36.04 & 34.28 & 32.52 & 30.75 & 28.99 & 27.23 & 25.46 & 23.70 & 21.94 & 20.17 & 18.41 \\
\hline \multicolumn{3}{|c|}{$\begin{array}{l}\text { The lateral blast costs } \\
\text { the equivalent of } 13 \% \\
\text { of the total }(1000 \$)\end{array}$} & 35.72 & 19.43 & 13.50 & 10.60 & 8.88 & 7.74 & 6.90 & 6.23 & 5.68 & 5.20 & 4.77 & 4.38 & 4.01 & 3.66 & 3.33 \\
\hline \multicolumn{3}{|c|}{$\begin{array}{l}\text { Blasting operation total } \\
\text { Cost }(1000 \$)\end{array}$} & 273.88 & 148.96 & 103.53 & 81.24 & \begin{tabular}{|l}
68.10 \\
\end{tabular} & \begin{tabular}{|l}
59.32 \\
\end{tabular} & 52.87 & 47.79 & 43.56 & 39.88 & 36.59 & 33.58 & 30.76 & 28.09 & 25.53 \\
\hline \multicolumn{3}{|c|}{$\begin{array}{l}\text { Blasting operation total } \\
\text { cost }\left(\$ / \mathrm{m}^{3}\right)\end{array}$} & 1.74 & 0.95 & 0.66 & 0.52 & 0.43 & 0.38 & 0.34 & 0.30 & 0.28 & 0.25 & 0.23 & 0.21 & 0.20 & 0.18 & 0.16 \\
\hline
\end{tabular}

a: $\mathrm{SC}\left(\mathrm{Kg} / \mathrm{m}^{3}\right)$ and $\mathrm{SD}\left(\mathrm{m} / \mathrm{m}^{3}\right)$ and $\mathrm{BC}\left(\mathrm{S} / \mathrm{m}^{3}\right)$, if $\left(\mathrm{y}<90^{\circ}\right)$
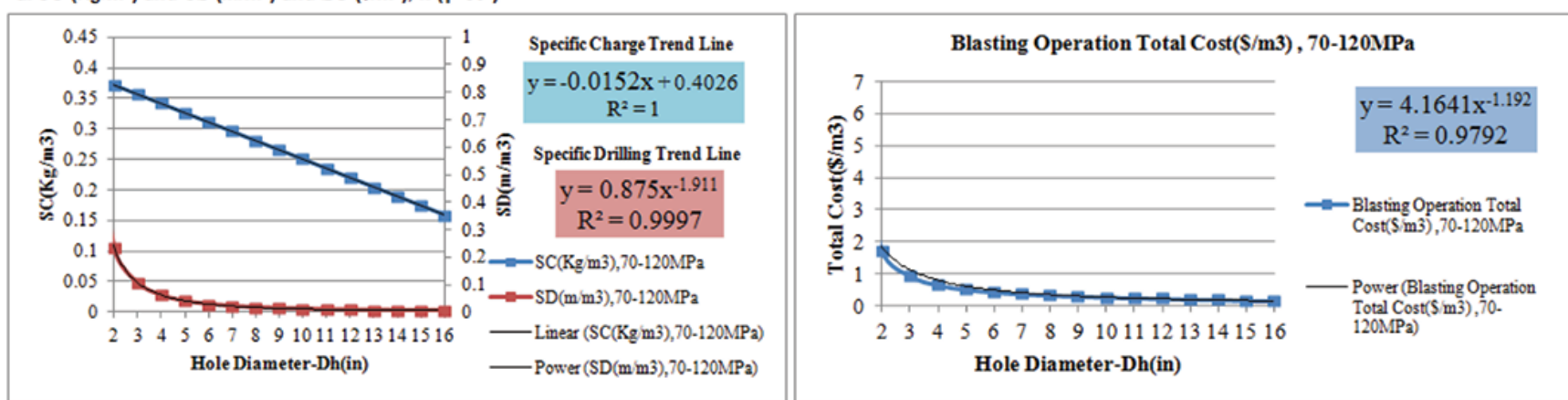

b: $\mathrm{SC}\left(\mathrm{Kg} / \mathrm{m}^{3}\right)$ and $\mathrm{SD}\left(\mathrm{m} / \mathrm{m}^{3}\right)$ and $\mathrm{BC}\left(\mathrm{S} / \mathrm{m}^{3}\right)$, if $\left(\mathrm{\gamma}>90^{\circ}\right)$
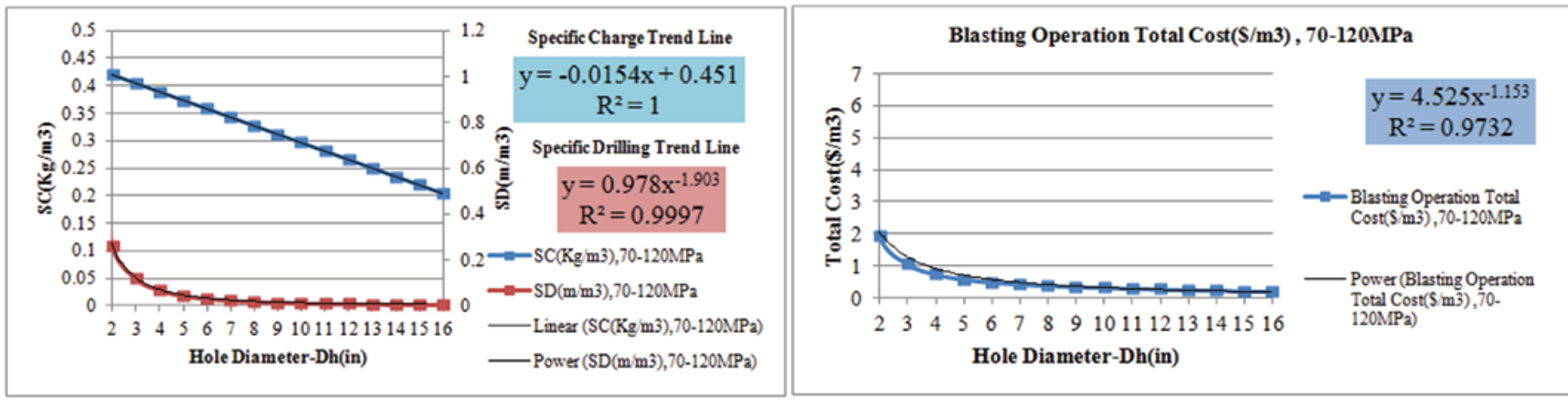

Figure 4-Relationship between specific charge (SC), specific drilling (SD), and blasting costs considering hole diameter in the UCS strength range (70-120 $\mathrm{MPa})$ for $\left(\gamma<90^{\circ}\right)$ and $\left(\gamma>90^{\circ}\right)$ 


\section{A model to calculate blasting costs using hole diameter, uniaxial compressive strength}

\begin{tabular}{|c|c|c|c|c|c|c|c|c|c|c|c|c|c|c|c|c|c|}
\hline \multicolumn{18}{|l|}{ Table XII } \\
\hline \multicolumn{18}{|c|}{ Calculations of blasting parameters and costs with UCS $120-180 \mathrm{MPa}$ and hole diameter of 2 to 16 inches } \\
\hline \multicolumn{2}{|c|}{ 120-180 MPa } & Dh (in) & 2 & 3 & 4 & 5 & 6 & 7 & 8 & 9 & 10 & 11 & 12 & 13 & 14 & 15 & 16 \\
\hline \multicolumn{2}{|c|}{ Ratio is rounded (m/in) } & $\mathrm{Dh}(\mathrm{mm})$ & 50.8 & 76.2 & 102 & 127 & 152 & 178 & 203.2 & 228.6 & 254 & 279.4 & 304.8 & 330.2 & 355.6 & 381 & 406.4 \\
\hline $\mathrm{B} / \mathrm{Dh}$ & 0.9 & $B(\mathrm{~mm})$ & 1800 & 2700 & 3600 & 4500 & 5400 & 6300 & 7200 & 8100 & 9000 & 9900 & 10800 & 11700 & 12600 & 13500 & 14400 \\
\hline $\mathrm{S} / \mathrm{Dh}$ & 1.1 & $\mathrm{~S}(\mathrm{~mm})$ & 2196 & 3294 & 4392 & 5490 & 6588 & 7686 & 8784 & 9882 & 10980 & 12078 & 13176 & 14274 & 15372 & 16470 & 17568 \\
\hline $\mathrm{T} / \mathrm{Dh}$ & 0.81 & $T(m m)$ & 1620 & 2430 & 3240 & 4050 & 4860 & 5670 & 6480 & 7290 & 8100 & 8910 & 9720 & 10530 & 11340 & 12150 & 12960 \\
\hline $\mathrm{J} / \mathrm{Dh}$ & 0.3 & $J(m m)$ & 594 & 891 & 1188 & 1485 & 1782 & 2079 & 2376 & 2673 & 2970 & 3267 & 3564 & 3861 & 4158 & 4455 & 4752 \\
\hline$\overline{\mathrm{SC}\left(\mathrm{kg} / \mathrm{m}^{3}\right)}$ & & & 0.42 & 0.40 & 0.39 & 0.37 & 0.36 & 0.34 & 0.33 & 0.31 & 0.30 & 0.28 & 0.27 & 0.25 & 0.24 & 0.22 & 0.20 \\
\hline \multicolumn{2}{|l|}{$\mathrm{SD}\left(\mathrm{m} / \mathrm{m}^{3}\right)$} & & 0.26 & 0.12 & 0.07 & 0.04 & 0.03 & 0.02 & 0.02 & 0.01 & 0.01 & 0.01 & 0.01 & 0.01 & 0.01 & 0.01 & 0.01 \\
\hline \multicolumn{3}{|c|}{ Drilling cost $(1000 \$)$} & 263.16 & 119.19 & 68.30 & 44.51 & 31.47 & 23.53 & 18.33 & 14.73 & 12.13 & 10.19 & 8.70 & 7.53 & 6.60 & 5.84 & 5.21 \\
\hline \multicolumn{3}{|c|}{ ANFO cost (1000\$) } & 48.66 & 46.87 & \begin{tabular}{|l|l|}
45.08 \\
\end{tabular} & 43.30 & 41.51 & 39.73 & 37.94 & 36.15 & \begin{tabular}{|l|}
34.37 \\
\end{tabular} & \begin{tabular}{|l|}
32.58 \\
\end{tabular} & 30.79 & 29.01 & 27.22 & 25.44 & 23.65 \\
\hline \multicolumn{3}{|c|}{$\begin{array}{l}\text { The lateral blast costs } \\
\text { the equivalent of } 13 \% \\
\text { of the total }(1000 \$)\end{array}$} & 46.77 & 24.91 & 17.01 & 13.17 & 10.95 & 9.49 & 8.44 & 7.63 & 6.97 & 6.42 & 5.92 & 5.48 & 5.07 & \begin{tabular}{|l|}
4.69 \\
\end{tabular} & 4.33 \\
\hline \multicolumn{3}{|c|}{$\begin{array}{l}\text { Blasting operation total } \\
\text { Cost }(1000 \$)\end{array}$} & 358.59 & 190.97 & 130.39 & 100.98 & 83.93 & 72.74 & 64.71 & 58.51 & 53.47 & 49.19 & 45.42 & 42.02 & 38.89 & 35.96 & 33.19 \\
\hline \multicolumn{3}{|c|}{ Blasting operation total } & 2.28 & 1.21 & 0.83 & 0.64 & 0.53 & 0.46 & 0.41 & 0.37 & 0.34 & 0.31 & 0.29 & 0.27 & 0.25 & 0.23 & 0.21 \\
\hline
\end{tabular}

a: $\mathrm{SC}\left(\mathrm{Kg} / \mathrm{m}^{3}\right)$ and $\mathrm{SD}\left(\mathrm{m} / \mathrm{m}^{3}\right)$ and $\mathrm{BC}\left(\mathrm{S} / \mathrm{m}^{3}\right)$, if $\left(\mathrm{r}<90^{\circ}\right)$
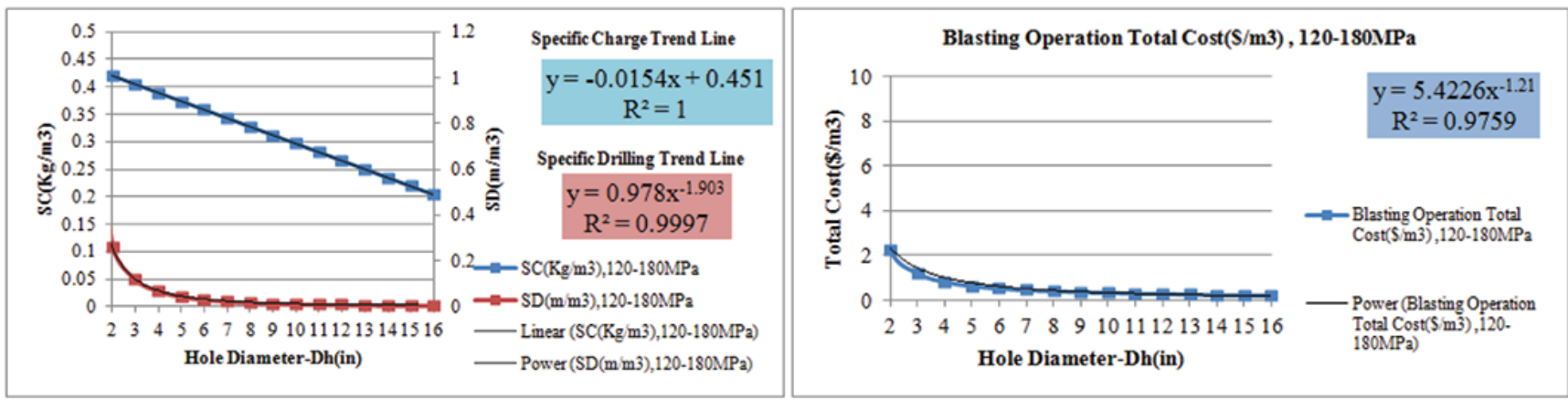

b: $\mathrm{SC}\left(\mathrm{Kg} / \mathrm{m}^{3}\right)$ and $\mathrm{SD}\left(\mathrm{m} / \mathrm{m}^{3}\right)$ and $\mathrm{BC}\left(\mathrm{S} / \mathrm{m}^{3}\right)$, if $\left(p 90^{\circ}\right)$
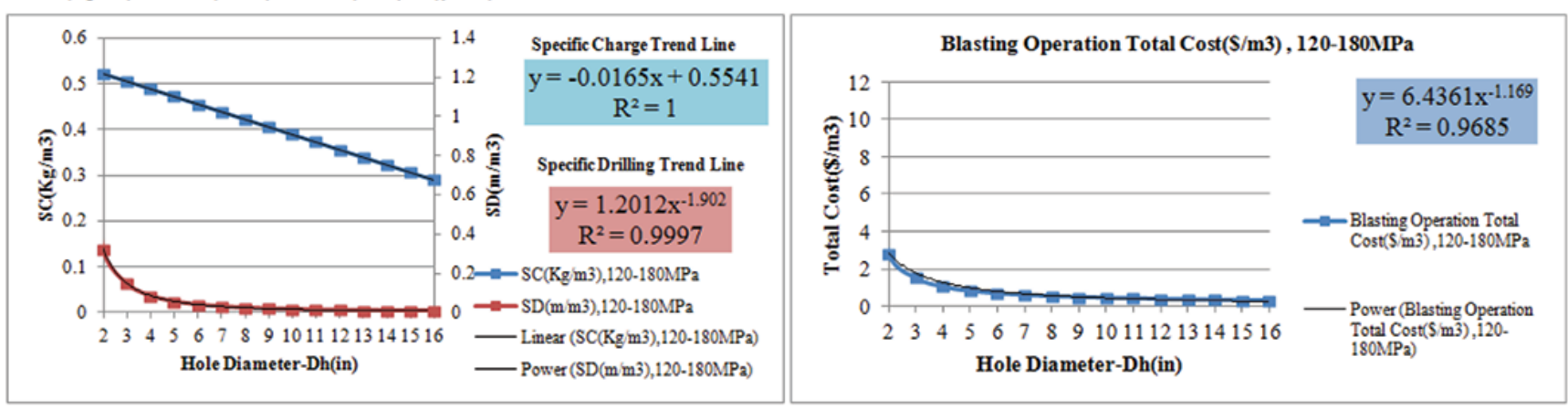

Figure 5-Relationship of specific charge (SC), specific drilling (SD), and blasting costs to hole diameter in the UCS range $120-180 \mathrm{MPa}$ for $\gamma<90^{\circ}$ and $\gamma>90^{\circ}$

\section{Results of reviews}

According to the research and the proposed models shown in the previous section, the relationship between the hole diameter and specific charge, specific drilling, and blasting costs for bench heights of $15 \mathrm{~m}$ in $\gamma<90^{\circ}$ and $\gamma>90^{\circ}$ are determined. The results are presented in Table XIV for the range of UCS considered.

Equation [5] shows the general equation of blasting cost, which is derived to calculate the blasting cost according to the hole diameter. In this equation, coefficients ' $a$ ' and ' $b$ ' are functions of bench height, UCS, join set orientation, the cost of drilling per metre, and the cost of ANFO.

$$
B C=1.15\left(P_{A} \times S C+P_{D} \times S D\right)=a(D h)^{-b}
$$

$B C_{e}$ in Table XIV is the estimated blasting cost during 2017. If the price of ANFO and drilling cost are fixed, blasting engineers can use $B C_{e}$ in Table XIV; otherwise, they can use $B C$ for calculating blasting cost, which excludes a time-frame. However, they should determine $P_{A}$ and $P_{D}$ for every year.

According to Table XIV, blasting cost was calculated using the UCS, hole diameter, and joint set orientation for Sungun, Miduk, and Chah-Firouzeh. In this model the blasting cost was calculated for each blast block, which includes drilling cost, the cost of ANFO, and auxiliary charges for the blasting operation. It should be mentioned that the 


\section{A model to calculate blasting costs using hole diameter, uniaxial compressive strength}

Table XIII

Calculations of blasting parameters and costs with UCS 180-250 MPa and hole diameter of 2 to 16 inches

\begin{tabular}{|c|c|c|c|c|c|c|c|c|c|c|c|c|c|c|c|c|c|}
\hline \multicolumn{2}{|c|}{$180-250 \mathrm{MPa}$} & Dh (in) & 2 & 3 & 4 & 5 & 6 & 7 & 8 & 9 & 10 & 11 & 12 & 13 & 14 & 15 & 16 \\
\hline \multicolumn{2}{|c|}{ Ratio is rounded (m/in) } & $\mathrm{Dh}(\mathrm{mm})$ & 50.8 & 76.2 & 102 & 127 & 152 & 178 & 203.2 & 228.6 & 254 & 279.4 & 304.8 & 330.2 & 355.6 & 381 & 406.4 \\
\hline $\mathrm{B} / \mathrm{Dh}$ & 0.84 & B (mm) & 1680 & 2520 & 3360 & 4200 & 5040 & 5880 & 6720 & 7560 & 8400 & 9240 & 10080 & 10920 & 11760 & 12600 & 13440 \\
\hline $\mathrm{S} / \mathrm{Dh}$ & 0.96 & $\mathrm{~S}(\mathrm{~mm})$ & 1915.2 & 2872.8 & 3830.4 & 4788 & 5745.6 & 6703.2 & 7660.8 & 8618.4 & 9576 & 10533.6 & 11491.2 & 12448.8 & 13406.4 & 14364 & 15321.6 \\
\hline T/Dh & 0.75 & $\mathrm{~T}(\mathrm{~mm})$ & 1495.2 & 2242.8 & 2990.4 & 3738 & 4485.6 & 5233.2 & 5980.8 & 6728.4 & 7476 & 8223.6 & 8971.2 & 9718.8 & 10466.4 & 11214 & 11961.6 \\
\hline J/Dh & 0.3 & $\mathrm{~J}(\mathrm{~mm})$ & 599.76 & 899.64 & 1199.52 & 1499.4 & 1799.28 & 2099.16 & 2399.04 & 2698.92 & 2998.8 & 3298.68 & 3598.56 & 3898.44 & 4198.32 & 4498.2 & 4798.08 \\
\hline \multicolumn{3}{|c|}{$\mathrm{SC}\left(\mathrm{kg} / \mathrm{m}^{3}\right)$} & 0.52 & 0.50 & 0.49 & 0.47 & 0.45 & 0.44 & 0.42 & 0.41 & 0.39 & 0.37 & 0.36 & 0.34 & 0.32 & 0.31 & 0.29 \\
\hline \multicolumn{3}{|c|}{$\mathrm{SD}\left(\mathrm{m} / \mathrm{m}^{3}\right)$} & 0.32 & 0.15 & 0.08 & 0.05 & 0.04 & 0.03 & 0.02 & 0.02 & 0.01 & 0.01 & 0.01 & 0.01 & 0.01 & 0.01 & 0.01 \\
\hline \multicolumn{3}{|c|}{ Drilling cost (1000 \$) } & 388.10 & 175.80 & 100.75 & 65.68 & 46.44 & 34.73 & 27.05 & 21.74 & 17.91 & 15.05 & 12.85 & 11.13 & 9.75 & 8.62 & 7.70 \\
\hline \multicolumn{3}{|c|}{ ANFO cost (1000 \$) } & 60.33 & 58.42 & 56.50 & 54.59 & 52.67 & 50.76 & 48.84 & 46.93 & 45.01 & 43.10 & 41.18 & 39.27 & 37.35 & 35.44 & 33.52 \\
\hline \multicolumn{3}{|c|}{$\begin{array}{l}\text { The lateral blast costs the equivalent } \\
\text { of } 13 \% \text { of the total ( } 1000 \$)\end{array}$} & 67.26 & 35.13 & 23.59 & 18.04 & 14.87 & 12.82 & 11.38 & 10.30 & 9.44 & 8.72 & 8.11 & 7.56 & 7.06 & 6.61 & 6.18 \\
\hline \multicolumn{3}{|c|}{$\begin{array}{l}\text { Blasting operation total } \\
\text { cost }(1000 \$)\end{array}$} & 515.70 & 269.36 & 180.85 & 138.31 & 113.98 & 98.31 & 87.28 & 78.97 & 72.36 & 66.87 & 62.14 & 57.95 & 54.16 & 50.67 & 47.40 \\
\hline \multicolumn{3}{|c|}{ Blasting operation total cost $\left(\$ / \mathrm{m}^{3}\right)$} & 3.27 & 1.71 & 1.15 & 0.88 & 0.72 & 0.62 & 0.55 & 0.50 & 0.46 & 0.42 & 0.39 & 0.37 & 0.34 & 0.32 & 0.30 \\
\hline
\end{tabular}

a: $\mathrm{SC}\left(\mathrm{Kg} / \mathrm{m}^{3}\right)$ and $\mathrm{SD}\left(\mathrm{m} / \mathrm{m}^{3}\right)$ and $\mathrm{BC}\left(\mathrm{S} / \mathrm{m}^{3}\right)$, if $\left(\mathrm{\gamma}^{\left.<90^{\circ}\right)}\right.$

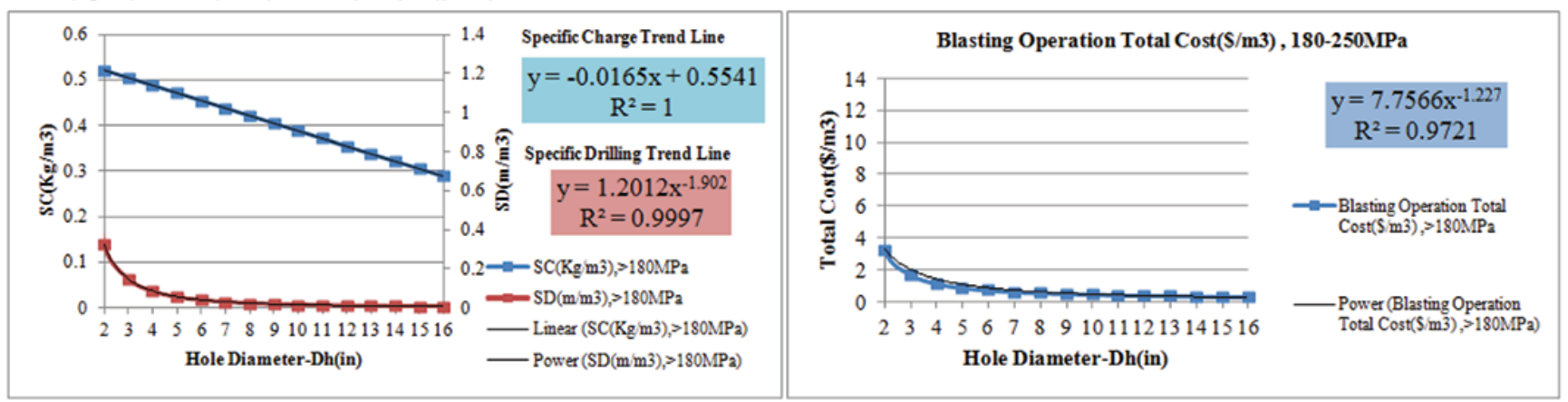

b: $\mathrm{SC}\left(\mathrm{Kg} / \mathrm{m}^{3}\right)$ and $\mathrm{SD}\left(\mathrm{m} / \mathrm{m}^{3}\right)$ and $\mathrm{BC}\left(\mathrm{S} / \mathrm{m}^{3}\right)$, if $\left(\gamma>90^{\circ}\right)$

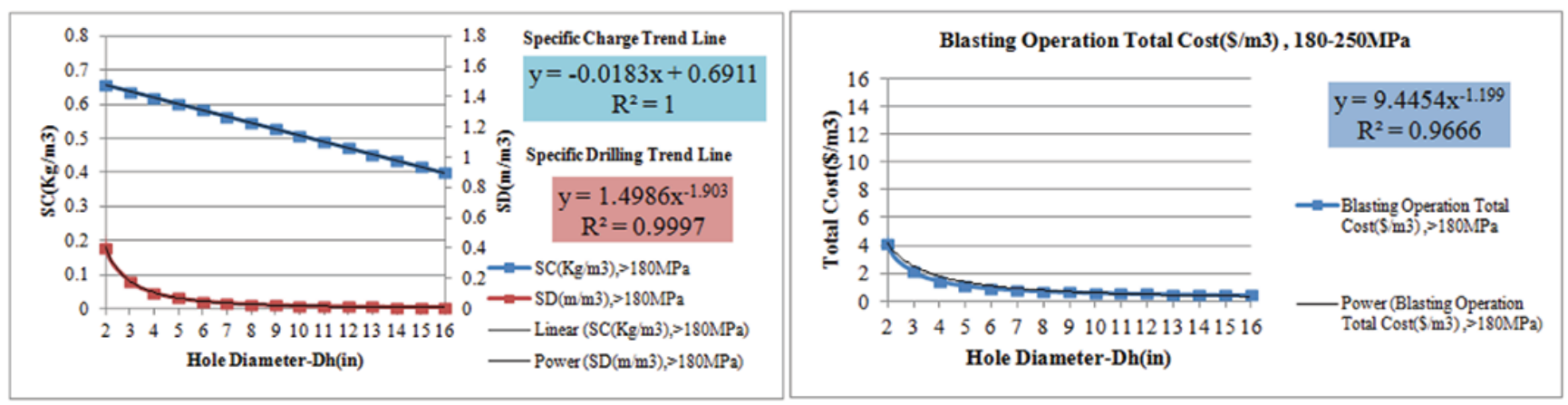

Figure 6 - Relationship of specific charge (SC), specific drilling (SD), and blasting costs considering hole diameter in the UCS range $180-250$ MPa for $\gamma<90^{\circ}$ and $\gamma>90^{\circ}$

blasting cost will increase with increasing rock strength and $\mathrm{r}$, and decrease with increasing hole diameter in all ranges of UCS.

\section{Conclusion}

Investigation of the blasting cost at Sungun, Miduk, and Chah-Firouzeh copper mines revealed that there is a relationship between hole diameter and blasting cost.
Generally, the relationship can be expressed as $B C=a\left(D_{h}\right)^{-b}$, where $D_{h}$ is the hole diameter in inches, $B C$ is blasting cost in US dollars per cubic metre, and coefficients ' $a$ ' and ' $b$ ' are a function of bench height, UCS, joint set orientation, drilling cost per metre, and ANFO cost per kilogram. The bench height considered was $15 \mathrm{~m}$. The values of coefficients ' $a$ ' and ' $b$ ' for various UCS ranges and values of $y$ (the angle between plane of the bench face and the plane of the main joint set) less than or greater than $90^{\circ}$ are as follows. 


\section{A model to calculate blasting costs using hole diameter, uniaxial compressive strength}

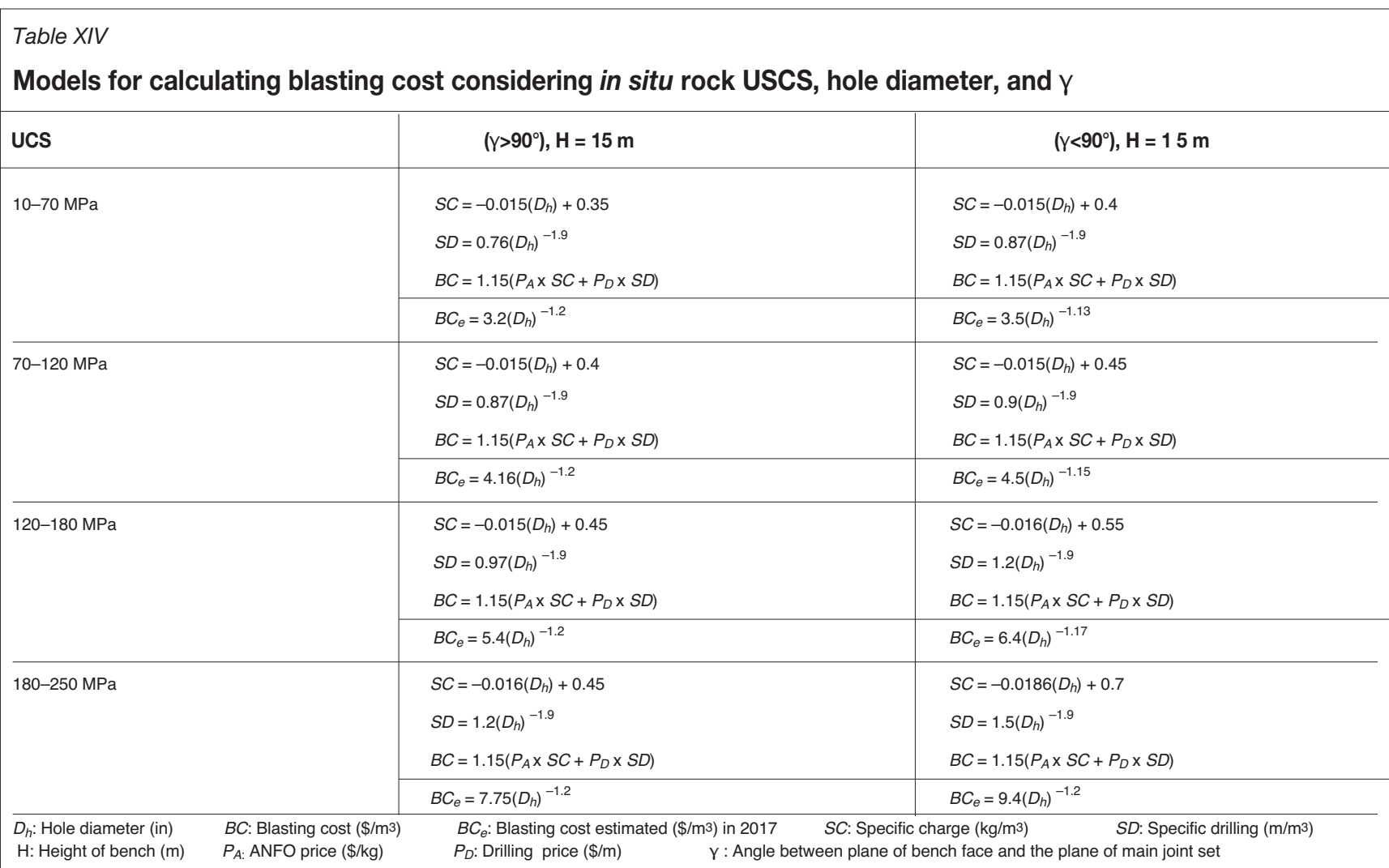

$\gamma<90^{\circ}$ :

\begin{tabular}{lll} 
UCS $(\mathrm{MPa})$ & Coefficient $a$ & Coefficient $b$ \\
\hline $10-70$ & 3.2 & 1.2 \\
$70-120$ & 4.16 & 1.2 \\
$120-180$ & 5.4 & 1.2 \\
$180-250$ & 7.75 & 1.2 \\
$\gamma<90^{\circ}$ & &
\end{tabular}

$\gamma<90^{\circ}$

\begin{tabular}{lll}
\hline UCS $(\mathrm{MPa})$ & Coefficient $a$ & Coefficient $b$ \\
\hline $10-70$ & 3.5 & 1.13 \\
$70-120$ & 4.5 & 1.15 \\
$120-180$ & 6.4 & 1.17 \\
$180-250$ & 9.4 & 1.2
\end{tabular}

This relationship shows that blasting costs will increase with increasing rock strength and $\gamma$ value, but will decrease with increasing hole diameter in every range of UCS.

\section{Acknowledgments}

The authors would like to express their thanks to the anonymous reviewer for his/her useful comments and constructive suggestions. The authors are also grateful to National Iranian Copper Industries Company and Zaminkavan-e-Gharn Company for providing information.

\section{References}

Adebayo, B. and AKAnde, J.M. 2015. Effects of blast-hole deviation on drilling and muck-pile loading cost. International Journal of Scientific Research and Innovative Technology, vol. 2. no. 6. pp. 64-73.

Adebayo, B. and Mutandwa, B. 2015. Correlation of blast-hole deviation and area of block with fragment size and fragmentation cost. International
Research Journal of Engineering and Technology (IRJET), vol. 2. pp. 402-406.

Afum, B.O. and Temeng, V.A. 2014. Reducing drill and blast cost through blast optimization: a case study. Proceedings of the 3rd UMaT Biennial International Mining and Mineral Conference. Ghana Mining Journal, vol. 15. no. 2. pp.137-145.

Cunningham, C. 2013. Blasting for construction some critical aspects. Civil Engineering, vol. 21. July 2013. pp.11-21.

Dehghan, M. 2001. Block Theory and Its Application to Rock Engineering, 1st edn. Shahrood University of Technology. $100 \mathrm{pp}$.

ELORANTA, J. 1995. Selection of powder factor in large-diameter blast holes. Proceedings of the 21st Annual Conference on Explosives and Blasting Techniques, Nashville, TN. International Society of Explosives Engineers. Vol. 1. http://elorantaassoc.com/download/Papers/E\&A_Powder_ Selection_Factor_in_Large_Diameter_Blast_Holes.pdf

GHANIZADEH ZARGHAMI, A. 2017. A model for calculating ANFO specific charge regarding the economic and geo mechanical parameters of copper mines in Iran. Science and Research Branch, Islamic Azad University, Tehran.

Ghanizadeh Zarghami, A., Shahriar, K., Goshtasbi, K. and AKBari, A. 2017. Assessing the most important economic parameters of surface mine blasting using ANP method. Proceedings of the 4th National Open Pit Mining Conference. Kerman, Iran, 14-17 May 2017. Iranian Society of Mining Engineering. pp. 9-19.

Ghanizadeh Zarghami, A. 2005. A Collection of Mining Engineering Software 1st edn. Dibagaran Tehran, Tehran. 474 pp.

Nenuwa, O.B. and Јıмон, B.O. 2014. Cost implication of explosive consumption in selected quarries in Ondo and Ekiti State. International Journal of Engineering and Technology, vol. 4. no. 7. pp. 402-409

Ostovar, R. 2013. Blasting In Mines. 9th edn. Vol. 1-3. Jihad Amirkabir University, Tehran. pp. 800.

PокRоvsку, M. 1980. Underground Structure and Mines Construction Practices. Chapter 1, Blasting Parameters. 13 pp.

Strelec, S., GAZdek, M,, AND Mesec, J. 2011. Blasting design for obtaining desired fragmentation. Technical Gazette. vol.18. pp. 79-86. 